\title{
Following the NAFTA Star: SADC land reform and investment protection after the Campbell litigation*
}

\author{
LONIAS NDLOVU \\ Senior Lecturer and Vice-Dean, Faculty of Commerce, Administration and Law, \\ University of Zululand
}

\section{INTRODUCTION}

For quite some time now, Zimbabwe has been in the regional and international spotlight for mostly negative reasons. The issue that placed Zimbabwe on the radar of regional and international attention was its land and agrarian policies of the 1990s. It has been argued by some commentators that with regard to the land question in Zimbabwe the past and present are inextricably interwoven. ${ }^{1}$ In order to understand the current state of affairs in the context of the subject of land reform and land acquisition, a holistic approach is a prerequisite. The implication is that it is imperative for anyone desiring to analyse or critically assess Zimbabwe's land reform programme and its ramifications to first take into account important historical events that shaped the programme with its present problematic dimensions.

Zimbabwe's land reform policies and laws have now moved beyond the country's own domestic sphere. So controversial did these policies become that the regional body, the Southern African Development Community (SADC), had to become involved. The legality of Zimbabwe's land reform laws was furthermore recently litigated at the SADC Tribunal. ${ }^{2}$ Following this case, referred to below as the Campbell case or dispute ${ }^{3}$, the problem has undoubtedly become a regional one.

\footnotetext{
* A revised version of this paper was presented at the 4th International Trade Law Conference hosted by the International Association of IT Lawyers in Barcelona, Spain, from 2-5 November 2010. My thanks to Dr Walter Joseph Ndaba, a colleague in the department of Private law, for comments and editorial work on an earlier draft. All errors and omissions remain my own.

1 This view is attributed to Magaisa AT, "The Land Question and Transitional Justice in Zimbabwe: Law, Force and History's Multiple Victims" at http://www.csls.ox.ac.uk/documents/ magaisaLandinZimbabweRevised290610.pdf (15/08/10).

${ }^{2}$ Hereafter 'Tribunal'. The SADC Tribunal, established by Article 9 of the SADC Treaty, is the highest legal and institutional body seized with responsibility for adjudicating regional disputes directly or
} 
The Campbell case revolved around the issue of the forcible expropriation of farm land without the compensation of land owners by the Zimbabwean government. However, there is a dimension to the dispute that the Tribunal did not comment on specifically; that is, the protection of investments in the SADC region. While it is true that the dispute was primarily about land reform laws and policies that were alleged to be discriminatory, racist and making no provision for compensation in an expropriation context, the findings do have serious implications for trade and investment protection in the SADC region.

In this paper, I attempt to analyse the Campbell case from a trade and investment protection perspective. This analysis is done by isolating the specific issues the Tribunal adjudicated upon and contextualising these issues to investment protection rather than land and agrarian reform per se. To effectively drive the point home, the pertinent provisions in the NAFTA ${ }^{4}$ and SADC Protocol on Investment are compared and analysed. In the process, important lessons are drawn for future SADC trade and investment protection.

To achieve the above objectives, the paper focuses on a number of pertinent issues. After a brief legal-historical background to Zimbabwe's land reform laws and policies, it gives an account of the facts and legal issues arising from the Campbell decision together with a cursory identification of emerging trade and investment issues. The investment issues identified are then contextualised by comparing NAFTA and SADC provisions on the issues so identified. Thereafter follows a brief discussion and analysis of relevant case law. In its conclusion, the paper sums up possible lessons the SADC can learn from NAFTA and makes a few suggestions for SADC law reform in a bid to indicate how a legal regime suited for investment protection may be established.

\section{A LEGAL HISTORICAL BACKGROUND TO ZIMBABWE'S LAND REFORM LAWS AND POLICIES}

\subsection{Preliminary remarks}

Some authorities and commentators ${ }^{5}$ simplistically suggest that Zimbabwe's land reform woes started in the late 1990s when Robert Mugabe and his ZANU (PF) party were faced with prospects of an imminent electoral defeat at the hands of a foreignsponsored party, the Movement for Democratic Change (MDC). It is submitted that

indirectly impacting on the realisation of the objectives of the Declaration and Treaty of the SADC, 1992.

${ }^{3}$ See Mike Campbell and Others v Republic of Zimbabwe SADC (T) Case No. 2/2007.

${ }^{4}$ North American Free Trade Agreement, between the United States and Mexico; discussed in detail in paras $5-6$ below.

5 See for instance Cousins B, "Why land invasions will happen here too": paper delivered at Symposium for Land Reform, University of Fort Hare, 1-4 July 2004. 
the issues are not that simple. ${ }^{6}$ Therefore a legalistic analysis of the rights and wrongs of the latest episode of conflict is unlikely to help resolve the enduring question of Zimbabwe's land reform, let alone satisfy concerned parties. ${ }^{7}$

It is important to point out from the start that the law was used throughout the colonial era to legitimise the expropriation of land, thus creating a set of victims whose interests were never satisfied at independence. This created a reservoir of grievances which ZANU (PF) exploited to its advantage from the 2000 elections to date. To somewhat adapt the writings of Saint $\mathrm{Paul}^{8}$ to the present context, it is accurate to state that "[i]n the beginning it was about land, it was about the land during the struggle, what the struggle was, the land was. It has remained thus about land today". ${ }^{9}$

To understand the Zimbabwean land issue in its proper context, it is important to highlight key social, legal and historical landmarks that have shaped the dimensions of the land issue into what it has become today.

\subsection{Colonial era to independence}

The history of conflict over land in Zimbabwe commenced with colonialism in 1890 when the land between the Zambezi and the Limpopo rivers was given to the British South Africa Company headed by Cecil John Rhodes. ${ }^{10}$ Between 1894 and 1895 "Native Reserves" were created for Africans to keep them separate from their white counterparts. ${ }^{11}$ This land distribution marked the beginning of segregation and forced removals of blacks from their ancestral land. Despite attempted uprisings against the forced removals to the reserves, the local African population was nevertheless defeated and subdued in the Matabele uprising of 1893 and the first chimurenga of 1896-1897.12

\footnotetext{
${ }^{6}$ Magaisa (fn 1 above) 1 . On the fallacy of the thesis that land reform problems in Zimbabwe are primarily about ZANU (PF) desperately seeking political self-preservation, see generally Palmer R. Land and Racial Domination in Rhodesia Heinemann Educational, London (1977) at 178 and Moyo S The Land Question in Zimbabwe SAPES Books, Harare (1995) 1.

7 Ibid.

8 The Gospel according to St Paul, Chapter 1 verse 1, New English Bible.

${ }^{9}$ This mimics the words of Sir Shridath Ramphal, Secretary-General of the Commonwealth from 1975 to 1990, in an interview with Gugulethu Moyo and Mark Ashurst cited in Magaisa (fn 1 above) 2.

${ }^{10}$ Magaisa (fn 1 above) 3. The Rudd concession was an agreement signed between Lobengula, king of the Ndebele and Cecil John Rhodes' emissaries. It is often said that in that agreement Lobengula gave away control of the land over which his powerful Ndebele monarchy ruled. For a detailed chronology of Zimbabwe's colonial legislation relevant to land reform, see Zimbabwe's Ministry of Lands and Agriculture at http://www.moa.gov.zw/ (accessed 15 June 2010).

${ }^{11}$ Magaisa (fn 1 above) 3.

${ }^{12}$ See generally Tshuma L, A Matter of Injustice - Law, State and the Agrarian Question in Zimbabwe SAPES Books, Harare (1997) 5-15. Chimurenga is a Shona word for uprising or rebellion.
} 
During the colonial era various legal instruments were enacted giving legal control of the land to the new settlers. ${ }^{13}$ This took the form of a disguised expropriation targeting only land in African hands and control and transferring it to whites, without payment of any form of compensation. In the 1918 case of In Re Southern Rhodesia ${ }^{14}$ the Privy Council confirmed that all unalienated land belonged to the British Crown and that land being expropriated from Africans was terra nullius; that is, not owned by any person because the local tribes were not sufficiently civilised to have developed any recognisable property rights over the land. ${ }^{15}$ The decision set a precedent justifying expropriation of land from African communities without compensation and aptly exposed the critical role played by the judiciary in the interpretation and enforcement of land expropriation rights. A plethora of legislative enactments was also to follow.

In the next sixty or so years the authority of the law was used to further encroach on Africans' right to own land. This was forcibly done under the auspices of the Land Apportionment Act ${ }^{16}$ and the Land Tenure Act. ${ }^{17}$ According to Palmer, the Land Apportionment Act had become something of a Magna Carta to whites, guaranteeing them the preservation of their way of life and insulating it from encroachment by hordes of blacks who saw the Act as blatantly discriminatory and palpably unjust. ${ }^{18}$ It is this injustice that fuelled the war of liberation that culminated in the birth of the new Zimbabwe.

The war of independence ended in 1979-80 and gave birth to the Lancaster House Constitution, a seriously flawed document that has haunted Zimbabweans up to today. The document was infamous for its weaknesses relating to the land issue. While the Patriotic Front ${ }^{19}$ preferred a constitution with provisions facilitating speedy land reform which would give to blacks an equitable share of the land, the Lancaster House Conference sought to achieve a political settlement which postponed the land problem. ${ }^{20}$ It has been argued that this Conference delayed the

\footnotetext{
13 According to the International Commission of Jurists (ICJ) Report of 1976 11-12, the objective of the legislation was to strengthen white dominion over the most fertile and economically important land while maintaining the African population as the labouring class.

14 (1919) AC 210.

15 Ibid. The Privy Council came to the conclusion that "whoever now owns the unalienated lands, the natives do not" (at 233).

16 Land Apportionment Act of 1930. According to Palmer (at 186) cited in Magaisa (fn 1 above) 6, when the Land Apportionment Act was finally passed in 1930, the country's 48000 Europeans (of whom only 11000 were settled on the land), were given on average 1000 acres per head of population. Their share was greater than that of the one million still predominantly rural Africans who had only 29 acres per head of population.

17 Land Tenure Act of 1969.

18 Palmer (fn 6 above) 134.

19 The Patriotic Front consisted primarily of ZANU (PF) and PF ZAPU, the main protagonists of the war of independence, led by Robert Mugabe and Joshua Nkomo at the Lancaster House constitutional talks. Mugabe later became Prime minister of the newly independent Republic of Zimbabwe with Joshua Nkomo grudgingly taking up the post of Minister of Home Affairs.

${ }^{20}$ Moyo (fn 6 above) 2.
} 
resolution of the land question in Zimbabwe by at least 30 years. ${ }^{21}$ The Lancaster House Constitution contained a clause ${ }^{22}$ which created an impervious and robust framework for the protection of property rights in the first ten years of independence. According to the clause, effectively insulated from any amendment during those ten years, government was precluded from embarking on a meaningful process of land redistribution because it had to be based on a "willing buyer, willing seller" principle. According to Moyo, ${ }^{23}$ land reform progress during the first decade and a half of independence was unsatisfactory because the "land supply side of the distribution effort [was at the time] the least transparent and the most contentious issue around which future conflicts will revolve". 24

\subsection{Legal and other manoeuvres post-Clause 16 to date}

The provisions of clause 16 of the Lancaster House Constitution were an obvious thorn in the side of government, hence one is not surprised by the plethora of legal and policy interventions introduced after $1990 .{ }^{25}$

In summary, the changes were characterised by a radical shifting of responsibility for land redistribution from the Zimbabwean state to the United Kingdom in the 1990s. In light of the above, it is not surprising that legal processes were accompanied by force and violence from 2000 onwards. It has been argued that the use of law and force to dispossess landowners of their properties along racial lines, especially after 2000 , echoed the colonial period. ${ }^{26}$ But the roles had been reversed. The white commercial farmers exchanged places with their black counterparts who had borne the brunt of the unjust legal system in the 1930s and 1960s. ${ }^{27}$

In 1991, section 16 of the Lancaster House Constitution was amended. ${ }^{28}$ The amendment specifically targeted provisions relating to the government's obligation to pay compensation for acquired land. Whereas section 16 mandated government to "pay promptly adequate compensation"29 to the landowner whose land was acquired for resettlement, the 1990 amendment only required "fair compensation" to be paid "within a reasonable time". The amendment thus watered down the state's obligations by substituting the requirement for "prompt" payment with "payment within a reasonable time" and changed "adequate" compensation to "fair". Later section 16 was amended to bar judicial challenges questioning the fairness of

\footnotetext{
${ }^{21}$ Africa All Party Parliamentary Group of the UK Parliament in its report on "Land in Zimbabwe: Past Mistakes, Future Prospects" (2009) at 26.

22 Section 16.

${ }^{23}$ Moyo (fn 6 above) 3.

${ }^{24}$ Ibid.

25 This period technically marked the beginning of the end of the "willing buyer, willing seller" impediment to land redistribution.

${ }^{26}$ Magaisa (fn 1 above) 9.

27 Ibid.

${ }^{28}$ Section 6 of the constitution of Zimbabwe Amendment (No. 11) Act 30 of 1990.

${ }^{29}$ Emphasis added.
} 
compensation as determined by the compensation committee set up in terms of the Land Acquisition Act. 30 The changes to the law were resisted by commercial farmers who brought legal challenges to court. In one leading case, Davies and Others $v$ Minister of Lands, Agriculture and Water Development, ${ }^{31}$ the constitutionality of the designation $^{32}$ of land under the 1992 Act was challenged. The Zimbabwean government won the case in both the High and Supreme Courts but it was apparent that the legal route was not yielding the desired results.

The critical question which kept being raised during this period was the contentious matter of who is responsible for the payment of compensation to farmers whose properties had been acquired by government. The government of Zimbabwe has traditionally placed the obligation on the British government, which had for years since independence been funding land reform under an unwritten arrangement allegedly reached at the Lancaster House talks. ${ }^{33}$ When the new Labour government came into power in 1997 with Tony Blair at the helm, Britain unequivocally indicated that she was not obliged to foot the compensation bill. ${ }^{34}$ This infuriated Mugabe beyond measure and triggered the events that culminated in the farm invasions of 2000 to date. ${ }^{35}$ While the invasions were roundly condemned internationally, and at the height of parliamentary elections in 2000, the government of Zimbabwe introduced another Constitutional Amendment Act which sought to legitimise the invasions already taking place and to expedite the land reform process. ${ }^{36}$ The amendment absolved the Zimbabwean government of the responsibility to pay compensation to farmers by shifting it to Britain, the former colonial power, while at the same time entrenching a provision that there would be no obligation on the Zimbabwean government to pay fair or adequate compensation.

Further legal changes were made in 2005 when Constitutional Amendment No. 17 was passed. What the amendment essentially purported to achieve was to oust

30 The Land Acquisition Bill was gazetted on 24 January 1992, giving birth to the Land Acquisition Act. In terms of s 16(2) of the Amendment, "No such law [authorising acquisition of land] shall be called into question by any court on the ground that the compensation provided is not fair". For a scholarly discussion of the Act and its ramifications, see Coldham S "The Land Acquisition Act, 1992 of Zimbabwe" (1993) 37 Journal of African Law at 82-88.

311994 (2) ZLR 294 (H).

32 The Minister had to proclaim selected farms/lands in the Government Gazette as chosen by the government for land redistribution. This act of "choosing" was called designating land for resettlement.

${ }^{33}$ Magaisa (fn 1 above) 11.

34 The repudiation came in the form of a letter written to the then Minister of Lands, Agriculture and Rural Development in Zimbabwe, the Honourable Kumbirai Kangai MP, by the then Secretary for International Development in the new British government, Ms Clare Short. The full text of the letter is available at http://www.swans.com/library/art9/ankomah5.html (accessed 6 July 2010).

35 For a full account of the land invasions and an analysis of legal issues arising, see Dube $\mathrm{M}$ and Midgley R "Land Reform in Zimbabwe: Context, Process, Legal and Constitutional Issues and Implications for the SADC Region" (2008) Monitoring Regional Integration in Southern Africa Yearbook 2008 at 9-15.

36 This was done through Constitutional Amendment No. 16 of 2000. 
the jurisdiction of the Zimbabwean courts from hearing land acquisition disputes. ${ }^{37}$ The constitutional amendments barring access to the courts in land reform disputes were challenged in the Campbell case that went before the regional court, the SADC Tribunal. The Zimbabwean government lost the case. It is to the dispute in this case that the contextualisation of Zimbabwe's land reform crisis now turns.

\section{WHAT REALLY HAPPENED IN THE CAMPBELL CASE?}

\subsection{Background and Context of Dispute}

William Michael Campbell instituted an action on his own behalf as the managing director of Mike Campbell (Pvt) Limited, the owner of the farm, Mount Carmell, as well as on behalf of his employees who lived on the farm with their families. ${ }^{38} \mathrm{His}$ complaint was directed at land acquisitions by the Zimbabwean government carried out under section 16B of the constitution of Zimbabwe. ${ }^{39}$ In essence, the effect of the constitutional amendment was to oust the jurisdiction of Zimbabwean courts to hear cases involving farmers objecting to the government's compulsory acquisition of their farms. ${ }^{40}$

The first attempt to acquire Mount Carmell by the government had been made in July 2001 and, after the High Court ruled that the purported acquisition was illegal, ${ }^{41}$ the property was invaded by war veterans in October $2001 .{ }^{42}$ No action was taken by the police to stem the invasion. After Constitutional Amendment no. 17 took effect on 14 September 2005 the applicants took their dispute to the Supreme Court, the highest judicial authority in Zimbabwe. The matter was lodged on 15 May 2006 and judgment was only delivered on 22 January 2008. The Supreme Court held that the Constitutional amendment was valid and the government could proceed to acquire Mount Carmell, the jurisdiction of the courts in that instance having been competently ousted. ${ }^{43}$

Meanwhile, in late October 2007, Mike Campbell (Pvt) Limited and William Michael Campbell filed an application with the SADC Tribunal in Windhoek, Namibia, challenging the acquisition by the Republic of Zimbabwe of agricultural

\footnotetext{
37 This would seem to be prima facie unconstitutional in Zimbabwe since the country's Constitution traditionally provided for the right to the protection of the law in $\mathrm{s} 18$ thereof.

${ }^{38}$ See Dube and Midgley (fn 35 above) 2. See further, Ruppel OC and Bangamwabo FX "The SADC Tribunal: A legal Analysis of Its Mandate and Role in Regional Integration" (2008) Monitoring Regional Integration Year Book 2008 at 5 - 9.

${ }^{39}$ Amendment No. 17 of 2005.

40 The amendment applies to all land designated by the Minister responsible for land as compulsorily acquired; such land is then owned by the state.

41 Mike Campbell (Pvt) Ltd and Another v Minister of National Security and others (Constitutional application No. 124/06, unreported case Supreme Court of Zimbabwe)

42 Dube and Midgley (fn 35 above) 2.

${ }^{43}$ See Mike Campbell (Pvt) Ltd v Minister of National Security Responsible for Land, Land Reform and Resettlement (SC 49/07)
} 
land known as Mount Carmell Farm. ${ }^{44}$ The applicants simultaneously filed an application in terms of Article 28 of the Protocol on Tribunal read with Rule 61(2)-5 of the Rules of Procedure of the SADC Tribunal for an interim measure restraining the government from removing the applicants from their land pending the determination of the matter. ${ }^{45}$ The interim relief sought by the applicants was granted by the Tribunal on 13 December 2007. These cases as well as other cases of 77 applicants were consolidated into one case. ${ }^{46}$ Other futile applications to intervene were lodged with the Tribunal until 17 June $2008 .{ }^{47}$

On 20 June 2008 the applicants referred the failure of the Zimbabwean government to comply with the Tribunal's decision regarding the interim relief granted to the Tribunal. ${ }^{48}$ The Tribunal established that a failure had indeed taken place and reported its finding to the SADC summit. ${ }^{49}$

\subsection{A Brief overview of the parties' submissions to the Tribunal}

The crux of the submission by Mike Campbell and the 77 other farmers was that:

a) the Zimbabwean government had acted in breach of its obligations under the SADC Treaty by enacting and implementing Amendment 17;50

b) all the lands acquired by the government from the respondent had been illegally acquired since the Minister responsible had failed to establish that he had applied reasonable criteria in order to satisfy himself that the lands to be acquired were reasonably necessary for resettlement purposes; 51

c) the applicants were denied access to the courts to challenge the legality of the compulsory acquisition of their lands; ${ }^{52}$

d) the applicants had been racially discriminated against since they were the only ones whose land had been compulsorily acquired under Amendment $17 ; 53$ and

\footnotetext{
${ }^{44}$ Campbell case para 1 at 4.

45 Ibid.

${ }^{46}$ Campbell case SADC (T) NO.2/2008.

47 The first one was filed by Albert Fungai Mutize and others (SADC (T) No. 08/2008) and the second by Nixon Chirinda and Others (SADC (T) No. 09/2008). Both cases were dismissed on the same ground, that the Tribunal did not have jurisdiction in disputes between persons inter se (applicants and those in the Campbell case). Under Article 15(1) of the Protocol on Rules of Procedure of the SADC Tribunal, the Tribunal has jurisdiction over disputes between persons and a state or between state parties to the SADC Treaty.

${ }^{48}$ Campbell case para 3 at 7.

${ }^{49}$ This was done pursuant to Art 32 (5) of the Protocol on Rules of Procedure of the SADC Tribunal.

${ }^{50}$ Campbell case para 5 at 12.

51 Ibid para 6 at 13.

52 Ibid para 7.

53 Ibid para 8.
} 
e) the applicants were denied compensation in respect of the lands compulsorily acquired from them. ${ }^{54}$

On the other hand, it was argued on behalf of the Zimbabwean government that the Constitutional Amendment was justified and the applicants' case lacked merit on the following bases:

a) the Tribunal did not have jurisdiction in the matter; ${ }^{55}$

b) the land acquisition process had been started on a willing-buyer-willingseller basis and whites by virtue of colonial history were in possession of most of the land suitable for agricultural purposes. This could not be construed as racism because the government had also acquired land from a few black Zimbabweans who possessed large tracts of land. ${ }^{56}$

c) the applicants would receive compensation under Amendment No.17;57 and

d) the applicants had not been denied access to the Courts; they could, if they wished to, seek judicial review. ${ }^{58}$

\subsection{The findings of the tribunal}

There were four issues which the Tribunal had to determine. ${ }^{59}$ The first was whether or not it had jurisdiction to hear the matter. The second was a determination of whether or not the applicants had been denied access to justice in Zimbabwe. The third was whether or not the applicants had been discriminated against on the basis of race. Finally, the Tribunal had to decide whether or not compensation was payable for lands compulsorily acquired from the applicants by the Zimbabwean government.

On the question of jurisdiction the Tribunal found that it indeed had jurisdiction to hear the matter because, in order to give effect to the principles of the Treaty as spelt out in Article 4 thereof, due consideration had to be given to SADC principles; in particular human rights, democracy and the rule of law. ${ }^{60}$

On the question whether the applicants had been denied access to justice in their home country, the Tribunal again ruled in the affirmative in that their agricultural lands had been compulsorily acquired without affording them the right of access to the courts and being afforded a fair hearing. ${ }^{61}$ The government of Zimbabwe was therefore held to have acted in breach of Article 4 (c) of the SADC Treaty.

\footnotetext{
54 Ibid para 9.

55 Ibid para 12 at 14

56 Ibid para 13.

${ }^{57}$ Ibid para 18 at 15.

58 Ibid para 20 at 16.

${ }^{59}$ See part III entitled "Issues for Determination" at pp 16-17 of the judgement.

${ }^{60}$ Campbell case at 25.

61 Ibid at 41.
} 
In respect of the allegation that the land reform programme was based on racial discrimination, the Tribunal found that the programme was indeed racist because it targeted white farmers and rewarded ruling party adherents. ${ }^{62}$ It is important to point out that according to the Tribunal, had the approach to the land reform issue not been arbitrary, had fair compensation been paid and had expropriated land been given to the poor, landless and other disadvantaged and marginalised individuals or groups, differential treatment of the applicants would not have constituted racial discrimination. ${ }^{63}$ This view was echoed in the finding of the Supreme court of Zimbabwe in a related case decided in 2001 where the judges observed that, if the land reform programme had been conducted lawfully with fair compensation being paid, there could have been no doubt that the form of discrimination would have been found to be fair. ${ }^{64}$

Finally, with regard to the question of compensation, the Tribunal ruled in favour of the applicants because it was apparent that, given the clear position under international law, 65 the applicants had the right to be compensated and the Government of Zimbabwe, as the expropriating authority, had a correlative duty to pay fair compensation. ${ }^{66}$ It was held further that the Government of Zimbabwe could not rely on its national law, that is, its Constitution, to avoid an international law obligation to pay compensation. ${ }^{67}$

\subsection{Aftermath of the case and further ramifications}

To date the Zimbabwean government has not yet complied with the Tribunal's ruling. 68 Zimbabwean courts have also poured scorn on the Tribunal's views regarding its own jurisdiction. ${ }^{69}$ However, in South Africa, the Tribunal ruling was given recognition when farmers approached the North Gauteng High Court to have the ruling registered in South Africa. In the High Court ruling the farmers were given

\footnotetext{
62 Ibid at 54.

63 Ibid.

${ }^{64}$ See in this regard Commercial Farmers Union v Minister of Lands 2001 (2) SA 925 (ZSC) at para 9.

65 In deciding the issue, the Tribunal referred to Article 21 (b) of the Protocol on the SADC Tribunal and rules of procedure, which enjoins the Tribunal to develop its own jurisprudence by having regard to applicable Treaties, general principles and rules of public international law, which are sources of law for the Tribunal.

66 Campbell case p. 56.

67 Ibid at 57.

68 According to one newspaper report in Business Report (23 July 2010) the Zimbabwean Minister of Justice, Mr Patrick Chinamasa, is quoted as defiantly challenging the Tribunal to make as "many such judgements as possible" so that Zimbabwe will ignore them. See also The Zimbabwe Situation at http://www.zimbabwesituation.org/?p=16026 (accessed 8 February 2011).

69 See, for instance, the case of Etheredge $v$ Minister of State for National Security Responsible for Lands, Land Reform and Resettlement and Another [HC 3295/08) [2009] ZWHHC 1 (4 February 2009) in which Gowora J remarked that the supreme law of Zimbabwe is as spelt out in the Constitution and there is no statute that puts the SADC Tribunal in a superior position to the courts of Zimbabwe.
} 
the go-ahead to attach Zimbabwean government properties in South Africa. ${ }^{70}$ The South African government, however, was reported to be seeking legal advice on the propriety or otherwise of the SADC Tribunal's jurisdiction over Zimbabwe despite the confirmation of the ruling by the North Gauteng High Court. The reality of the matter is that the Tribunal ruling has met with contempt, not only from the Zimbabwean government but also from its judiciary.

The developments narrated in the foregoing paragraph are unfortunate and unnecessary when due consideration is given to the effect and review of the Tribunal decisions. The Tribunal's decisions and rulings are final and binding. ${ }^{71}$ The implication of this is that there is no further instance of appeal within the legal regime of SADC to review a decision or ruling issued by the Tribunal. ${ }^{72}$ Zimbabwe's refusal to comply may therefore be regarded as breaching SADC law and thus as totally unreasonable. Although the absence of an appellate mechanism for the SADC Tribunal was not raised by Zimbabwe, this deficiency may be regarded as a major weakness of the system. Neither did the Zimbabwean government take advantage of the review procedure provided for in Article 26 of the Tribunal's rules of procedure..$^{73}$ This procedure was available, but whether it could have been legally sustainable had Zimbabwe raised it remains moot. The fact that Zimbabwe has refused to abide by the SADC ruling and "gotten away" with such a palpable breach of the rules points to a major weakness of the Tribunal. SADC, as a regional grouping, must strengthen the legal provisions of its instruments. Tightening the legal loopholes in this regard would make it very difficult, if not impossible, for a litigant to ignore the Tribunal's rulings.

\subsection{Does the dispute have any investment implications?}

The Campbell dispute may be regarded as an investment dispute with serious implications for international investment law. International investment law generally prohibits discriminatory expropriations on the basis of race, with the notable exception being reserved for post-colonial expropriations aimed at ending the economic domination of nationals of the former colonial power. ${ }^{74}$ The Tribunal, as we saw earlier, used an international human rights approach in adjudicating the matter at hand..$^{75}$ It was, however, also possible to apply investment law principles

\footnotetext{
70 This however has been delayed because the South African government has intervened and asked for a postponement of the auction of the properties.

${ }^{71}$ Art 24(3) of the SADC Protocol on Tribunal and Rules of Procedure.

72 Ruppel (fn 38 above) 18.

${ }^{73}$ In terms of Art 26, such an application for a review of the Tribunal's decision may be brought upon discovery of some fact which by its nature might have had a decisive influence on the decision if it had been known to the Tribunal at the time the decision was given, but which at the time was unknown to both the Tribunal and the party making the application.

${ }^{74}$ See Zongwe DP "Contribution of Campbell v Zimbabwe to the Foreign Investment Law on Expropriations" (2009) 5 CLPE Research Paper at i.

75 Zongwe (fn 74 above) at 4 .
} 
to the Campbell dispute because of the foreign nationality or British origins of some of the corporations and farmers whose lands were expropriated. ${ }^{76}$ In the case of Funnekotter $v$ Zimbabwe, ${ }^{77}$ for example, the applicants were Dutch and Italian nationals. They claimed that the Zimbabwean government violated a bilateral investment treaty between the Netherlands and Zimbabwe by inter alia enacting and actualising Amendment No. 17.78

In this case the International Centre for Settlement of Investment Disputes (ICSID) awarded damages to Dutch foreign investors whose property had been expropriated without the necessary compensation as provided for in the bilateral investment treaty. ${ }^{79}$ Zimbabwe refused to comply with the award. ${ }^{80}$

On 17 June 2010, in a related matter, the German government complained to the Zimbabwean government, through its ambassador in Harare, that the occupation of three farms owned by a German investor in Zimbabwe amounted to a violation of bilateral and international agreements between the two countries.81 The complainant also stated that the German Embassy noted with concern that property rights of German nationals and their investments in Zimbabwe were being put under threat in clear violation of international law. ${ }^{82}$ Closer to home, on 18 June 2010, a South African civil rights initiative, AfriForum, was reported to be on the verge of taking legal action against the South African government for failing to protect the lives and property of South African farmers in Zimbabwe. ${ }^{83}$ According to the Chief Executive Officer of AfriForum, Mr. Kallie Kriel, the South African government had not taken any steps to assist South African citizens in Zimbabwe, even after it had come to light that attacks against South African establishments were increasing.

\footnotetext{
76 Zongwe (fn 74 above) at 4.

77 Bernardus Henricus Funnekotter and others v Republic of Zimbabwe (ICSID case no. ARB/05/6), decision of 2 April 2009.

78 The specific treaty was the Agreement on Encouragement and Reciprocal Protection of Investments between the Republic of Zimbabwe and the Kingdom of the Netherlands, 11 December 1996.

${ }^{79}$ Ibid.

80 See Schlemmer EC "Protection of Investors and Investments" (2009) SA Merc LJ 734 at 746.

81 Bilateral Investment Promotion and Protection Agreement (BIPPA) between Zimbabwe and Germany (1995) which came into force in 2000. See, further, "Germans Fume over Farm Seizures" reported in New Zimbabwe at http://www.newzimbabwe.com/news-2669-germans+fume +over+farm (accessed 18 June 2010).

82 Ibid. The international law referred to here is international investment law and the basic requirements that expropriations must be carried out as a last resort after taking into account that the process is for a public purpose, non-discriminatory and accompanied by the payment of compensation. These requirements form part of customary international law and must be met cumulatively (Zongwe, fn 74 above at 7). See further Dolzer R and Schreuer C Principles of International Investment Law Oxford University Press (2008) 89.

83 See "AfriForum to Take Legal Steps against SA Government over Zim Land Attacks" (18 June 2010) at http://allafrica.com/stories/201006210115.html (accessed 8 February 2011).
} 
It is also important to point out that South African farmers and their land are meant to be protected by a signed and recently ratified bilateral investment agreement between the two countries. ${ }^{84}$ In terms of the agreement's Preamble, the two countries entered into the agreement because they desired to create favourable conditions for greater investment by South African investors in Zimbabwe. The same holds for Zimbabwean investors in South Africa. ${ }^{85}$ The agreement is meant to protect all South African investments, including farms. With specific reference to farms, while security of tenure for all existing and new South African investments in Zimbabwe is guaranteed, historical claims arising out of the land reform process are excluded. ${ }^{86}$

Now that it has been established that the Campbell case could have been brought before the Tribunal as an investment dispute, it is appropriate to engage in legal speculation and surmise what the result would have been had the investment protection route been adopted. Since the SADC Protocol on Investment is not yet in operation, the matter could have been argued as a violation of customary international investment law. ${ }^{87}$ It is submitted that in order to have brought the dispute to the Tribunal as an investment dispute, the cause of action could easily have hinged on the absence of compensation. ${ }^{88}$ For an applicant to succeed in a claim that the expropriation is illegal, he or she needs to establish that the state as respondent did not satisfy any one of the three requirements for lawful expropriations, rather than all of them. ${ }^{89}$ It could therefore have been possible to present the Campbell case as an investment dispute premised on non-payment of compensation in violation of customary international investment law. It would then have been possible to have avoided references to racial discrimination which, with all due respect, the Tribunal got muddled up. ${ }^{90}$ The result would have been a finding

\footnotetext{
${ }^{84}$ The Bilateral Agreement for the Promotion and Reciprocal Protection of Investments (BIPPA) was signed in Harare on 27 November 2009 but will only become binding after reciprocal exchange of notifications to the effect that constitutional requirements for entry into force have been complied with. The BIPPA therefore has not come into force for want of such notifications.

85 For an exhaustive discussion of the implications and ramifications of the BIPPA, see Brand J and Krynauw M "Implications and Ramifications of Zimbabwe/SA Agreement on Investment Protection" at http://www.bowman.co.za/lawArticles/Law-Article id 132417448.asp (accessed 8 August 2010).

${ }^{86}$ Brand and Krynauw (fn 85 above) at 2.

87 For a conspectus of views on the subject of customary international investment law see generally Dodge WS "Customary International Law and the Question of Legitimacy" (2007) 120 Harvard Law Review Forum 19-27; Vicuna FR "Foreign Investment Law: How Customary is Custom?" (2005) 99 American Society of International Law 97-101; OECD Secretariat (2004) "Indirect Expropriation and the Right to Regulate in International Investment Law", Working Papers on International Investment number 2004/4 2-22 and Vagts D.F International Relations Looks at Customary International Law: A Traditionalist's Defence (2004) 15 The European Journal of International Law 1031-1040.

88 Amendment No. 17 did not only contemplate ousting the jurisdiction of the Zimbabwean courts to hear disputes involving land. It further allowed the government to pay the aggrieved farmer only for improvements on the land and nothing more.

${ }^{89}$ See the requirements enumerated in Zongwe (fn 74 above) at 25.

${ }^{90}$ It is common cause that most of the land the government of Zimbabwe wants to acquire

compulsorily is in the hands of white Zimbabweans due to historical and economic reasons. The fact
} 
by the Tribunal that the absence of compensation for expropriation rendered the land reform programme illegal, ending in a triumphant outcome for customary international investment law in general and the farmers in particular.

On the other hand, even if the Tribunal had gone ahead and analysed Amendment No. 17 from a racial discrimination point of view, as long as the cause of action was the absence of compensation in an investment protection context the result would have been the same. The implication would be that if authorities were to expropriate property in a bid to address economic inequalities occasioned by colonialism, but in a manner based on race and providing no compensation to the plaintiffs, then such an expropriation would be illegal even if it is motivated by the need to redress past economic inequalities brought by colonialism. ${ }^{91}$ In light of the foregoing it is submitted that the Campbell dispute was in the first place about investment protection. As a result it is submitted that disputes of such a nature can and should be brought to the Tribunal as investment disputes. This would leave the plaintiff with a number of viable remedial options to compel the reluctant respondent state to make good the plaintiff's losses.

Having made the case that the Campbell dispute could easily have been handled as an investment dispute, it is now appropriate to expound on the legal regime applicable to investments and their protection in an SADC context.

\section{SADC INVESTMENT PROTECTION PROVISIONS}

\subsection{Preliminary remarks}

Unlike NAFTA, which has elaborate investor and investment protection provisions as part of its main agreement, SADC has a separate instrument, the Protocol on Finance and Investment, which purports to protect investments in the region. ${ }^{92}$ Further, the Protocol has additional annexures which provide additional information about specific issues cursorily referred to in the Protocol itself. ${ }^{93}$ It is important, however, to point out at the onset that the Protocol has not yet come into operation because the required number of ratifications has not yet been deposited with the SADC Secretariat. ${ }^{94}$

If an investment dispute were to rise in an SADC context, the applicable law would be customary international investment law. To qualify as customary international law, a principle must result "from a general and consistent practice of

that white-owned farms were targeted does not in any way make Zimbabwe's land reform a racist project.

91 Zongwe (fn 74 above) at 26.

${ }^{92} \mathrm{~A}$ full text of the protocol is available at http://www.sadc-tribunal.org/pages/protocols.htm (accessed 5 August 2010).

${ }_{93}$ Annexures 1-11. Annexure 1 deals with the protection of investment generally.

${ }_{94}$ Per Schlemmer (fn 80 above) at 750. 
states followed by them from a sense of legal obligation". ${ }^{95}$ With specific reference to the SADC, while the Tribunal has the mandate to develop its own jurisprudence, it must also take into account applicable treaties, general principles and rules of public international law and any rules and principles of the law applicable in member states. ${ }^{96}$ Zimbabwe is a member of the SADC and is therefore subject to customary international law rules which emanate from public international law as referred to above.

NAFTA is an agreement that is binding between the United States, Canada and Mexico and, as such, its text does not constitute customary international investment law. The SADC Tribunal is not enjoined to follow NAFTA Tribunal decisions because those decisions are not binding on it. However, because NAFTA and the SADC belong to the same legal family in terms of WTO law, ${ }^{97}$ NAFTA jurisprudence may have immense persuasive value to SADC judges sitting as the Tribunal. In this paper, a discussion of the NAFTA provisions is meant to serve the purpose of persuading the SADC Tribunal to draw some useful lessons from NAFTA jurisprudence. It is not contended that NAFTA law must become SADC law, neither is it the intention of this paper to imply that NAFTA rules are applicable to Zimbabwe.

\subsection{Important provisions of the Protocol as elaborated by the Annexures}

The SADC Protocol is primarily about the harmonisation of the financial and investment policies of member states in order to make them consistent with the objectives of the regional grouping. ${ }^{98}$ Further, state parties are enjoined to create a favourable investment climate within SADC with the aim of promoting and attracting investment in the region. ${ }^{99}$ The definition of the term "investment" in the Protocol includes the acquisition of movable and immovable property including mortgages, liens or pledges. ${ }^{100}$ Also included in the definition of investment are shares, stocks and debentures of companies or interest in the property of such companies. ${ }^{101}$

\footnotetext{
95 McGinnis J0 “The Comparative Disadvantage of Customary International Law" (2006) 30 Harvard Journal of Law and Public Policy 7 at 9.

${ }^{96}$ Per Art 21 (b) of the Protocol on Tribunal and the Rules of Procedure Thereof. See also Ruppel (fn 38 ) at $16-18$.

97 NAFTA is a free trade area while SADC is a customs union. Both organisations are established pursuant to the WTO provisions in Article XXIV of GATT 1994 which allows countries to form regional integration agreements which may take the form of free trade areas and customs unions or other arrangements at the conclusion of which free trade areas or customs unions may be formed.

98 Preamble to SADC Protocol on Finance and Investment.

${ }^{99}$ Art 2 (a) of the Protocol.

100 Art 1 (a) of the Protocol.

${ }^{101}$ Art 1 (b) of the Protocol.
} 
Countries are generally allowed to admit investments into their territories in accordance with their national laws and regulations. ${ }^{102}$ This scenario may sound disturbing if one considers that some national laws may be so deficient as to be almost arbitrary. ${ }^{103}$ This result may call for an imposition of basic standards which member states must abide by, with each departure from the prescribed path considered as an actionable transgression. ${ }^{104}$

Administrative measures obtaining in a state must promote and create a predictable investment climate wherein the laws are not arbitrarily, and without good reason, amended to the detriment of investors. ${ }^{105}$ In order to promote investment, SADC member states are required to promote predictability, confidence, trust and integrity by adhering to and enforcing transparent policies, practices, regulations and procedures relating to investment. ${ }^{106}$ Transparency and predictability of the investment regime is further enhanced by competent judicial and administrative tribunals with the power of judicial review, including the review of measures relating to expropriation or nationalisation and the determination of compensation in the event of nationalisation or expropriation. ${ }^{107}$

As regards the settlement of investment disputes, clear guidelines are given in the Protocol. ${ }^{108}$ The settlement of such disputes shall be guided by the principles of cooperation and consultation to achieve consensus in the interpretation and application of the Protocol. ${ }^{109}$ In situations where parties are unable to achieve such consensus, two possible routes may be adopted. ${ }^{110}$ The first applies to situations where parties have divergent and mutually exclusive interpretations of a specific provision of the Protocol where there are provisions in the Annexure to the Protocol dealing with the same issue. ${ }^{111}$ In this instance the provisions of the Annexure would be used as interpretive guidelines. ${ }^{112}$ If the parties' dispute cannot be settled by reference to the Protocol or any of its Annexures, then parties must use their best endeavours to settle such dispute through negotiation in good faith. ${ }^{113}$ If negotiations fail within three months of the dispute arising, then the matter may be

\footnotetext{
102 Art 2 of the Protocol.

${ }^{103}$ Leaving the regulation of the protection of investments entirely to each country's discretion could have unfortunate results such as the circumstances that led to the Campbell litigation.

104 The Tribunal would have to come in as the final arbiter in this instance but there is an additional impediment in the form of the requirement that, before a litigant approaches the Tribunal, local remedies must be exhausted first [Art 15(2), SADC Tribunal rules].

${ }^{105}$ Art 2 (3) of the Protocol.

106 Art 8 of the Protocol.

${ }^{107}$ Art 27 of the Protocol.

${ }^{108}$ Art 24 of the Protocol, which specifically deals with the settlement of investment disputes, may be seen as a possible equivalent of NAFTA Chapter 11.

${ }^{109}$ Art 24 (2) para 1 of the Protocol.

110 Art 24 (2) of the Protocol.

111 Namely Annexure 1 to the Protocol on Finance and Investment.

112 Art 24 (2) para (a).

${ }^{113}$ Art 24 (2) para (b).
} 
referred to the SADC Tribunal. This would have been the route to adopt had the Campbell case been brought to the tribunal as an investment dispute.

Since one of the main objectives of this article is to extract investment protection lessons for SADC from NAFTA, it is now opportune to turn to an expository discussion and analysis of the pertinent NAFTA jurisprudence before specific lessons are highlighted.

\section{EXCERPTS FROM NAFTA CHAPTER 11 JURISPRUDENCE AND POSSIBLE LESSONS FOR SADC}

\subsection{General}

In the following disputes, despite the fact that most of the measures complained against were environmental in nature, the application of NAFTA investment principles such as the avoidance of expropriation are clearly laid out. Therefore the jurisprudential value of the cases lies in how the principles of investment protection were applied in an environmental protection context.

A juridical analysis of the Chapter 11 provisions of NAFTA indicates that there is likely to be tension between the sovereign authority of national or local governments to set environmental rules and the agreed right of a foreign investor to secure its investments against expropriation ${ }^{114}$ as well as against discriminatory or arbitrary treatment by a host state. A foreign investor enjoys the right to compensation in the event of a NAFTA member expropriating its property or adopting a measure "tantamount to expropriation". ${ }^{115}$

The words "tantamount to expropriation" have been the subject of debate in cases that alleged that an environmental regulation or policy constituted a measure tantamount to expropriation. ${ }^{116}$ There is no consensus as to what constitutes a measure tantamount to expropriation. However, environment-related claims in

\footnotetext{
114 The envisaged forms of expropriation that have come under consideration as subjects of disputes are direct expropriation, which occurs when a host state takes property owned by a foreign investor located in the host state, ostensibly for a public purpose, and indirect expropriation, which refers to actions, omissions or measures attributable to a government that are the functional equivalent of an expropriation. See Soloway J "Environmental expropriation under NAFTA Chapter 11: The Phantom menace" in Kirton JJ and Maclaren VW (eds) Linking Trade, Environment and Social Cohesion: NAFTA experiences, Global challenges (2002) 131-142.

115 NGOs are, however, concerned that the NAFTA provisions on expropriation are undesirable as they erode national sovereignty by limiting the capacity of governments to regulate in sensitive areas such as environmental conservation.

116 The cases are Pope and Talbot v Canada (2002) 41 ILM 1347; SD Myers Inc v Canada, Partial award

13 November 2000, Ethyl Corporation $v$ Canada (records available at http://www.international.gc.ca/trade-agreements-accords-commerciaux/disp-

diff/SDM archives.aspx?lang=en, accessed 8 February 2011); and Metalclad v United Mexican States, 2000 (available at http://ita.law.uvic.ca/documents/MetacladAward-English.pdf, accessed 8 February 2011).
} 
which investors have received or been awarded compensation provide some evidence as to how investment protection has been bolstered under NAFTA Chapter 11.

\subsection{Pope and Talbot v Canada}

In this case Pope and Talbot, an American firm with some business presence in Canada, argued that certain export restrictions by Canada resulted in a measure tantamount to expropriation since they had "deprived the investor of its ordinary ability to alienate its product to its traditional and natural market". ${ }^{117}$ Canada, for its part, contested the characterisation of the right to export lumber as a property right.

First, the Tribunal ruled that investment access to the US market is a property interest subject to protection under article 1110,118 thus implying that a measure that affected the value of such a property interest could be subject to challenge under article 1110.

Second, the Tribunal affirmed that for a measure to be considered expropriatory it need not be discriminatory. In other words, the Tribunal contemplated that in certain circumstances government measures could be applied in a nondiscriminatory manner, yet still be tantamount to expropriation. To find otherwise, the Tribunal opined, would leave a "gaping loophole" in international protection against expropriation. ${ }^{119}$

Third, the Tribunal gave a wide meaning to what measures could amount to expropriation. While stating that there was no expropriation in this case in terms of the "ordinary meaning" of the term, it also stated that a taking could include interference with the carrying on of business. The Tribunal was of the opinion that, while the interference in the case had - according to the investor - resulted in reduced profits on the investment, it continued to export substantial quantities of softwood lumber to the US and earned substantial profits on those sales. The Tribunal added that, while it may sometimes be uncertain whether a particular interference with business activities amounts to an expropriation, the test was whether that interference is sufficiently restrictive to support a conclusion that the property has been taken from the owner ${ }^{120}$ and that a finding of expropriation would require a substantial deprivation. ${ }^{121}$

Fourth and finally, the Tribunal narrowed the scope of the expropriation provisions by rejecting the investor's claim that the use of the term "tantamount to

\footnotetext{
117 Pope and Talbot $v$ Canada, Statement of Claim, para 93.

118 Pope and Talbot v Canada, Final Merits Award, para 96. This Article contains a prohibition against direct or indirect nationalisation or expropriation of an investment of an investor of another NAFTA party unless the nationalisation or expropriation meets certain specific requirements.

119 Pope and Talbot v Canada, Interim Award, paras 81-86.

120 Emphasis added.

121 Pope and Talbot v Canada, Final Merits Award, paras 101-102.
} 
expropriation" means something more than an outright taking or creeping expropriation. The Tribunal stated that "tantamount means nothing more than equivalent" and that "something equivalent cannot logically encompass more". ${ }^{122}$

In this case, therefore, the Tribunal adopted a relatively conservative approach to the interpretation of expropriation. This approach is buttressed by the fact that the Tribunal articulated a test of substantial deprivation and limited the meaning of "tantamount to expropriation" to nothing more than what would otherwise be a direct expropriation. This position is consistent with international jurisprudence on the subject of expropriation of alien property. In the premises, therefore, the Tribunal found that expropriation had not taken place.

\subsection{SD Myers Inc v Canada}

SD Myers Inc, a US company with branches in countries outside the US, ${ }^{123}$ is an electrical equipment repair and maintenance company that developed, as an outgrowth of its core business, a separate business of remediation of PCB contamination through the destruction of PCBs. ${ }^{124}$ Eastern Canada, with a considerable amount of PCB-contaminated equipment but no local disposal capacity, was another attractive opportunity for the company. However, the move was thwarted by the fact that, even though the terms of the bilateral agreement between the US and Canada allowed for cross-border movement of hazardous waste for environmentally sound disposal, regulations pursuant to the US Toxic substances control Act ${ }^{125}$ virtually banned the importation of PCBs into the US. To overcome this obstacle, SD Myers Inc established a branch in Canada in 1993 and began to lobby both US and Canadian environmental officials for a relaxation of the ban on PCBs from Canada to the US. This effort was supported by many East Canadian firms, which believed that the disposal of their PCBs by SD Myers in the US would be cheaper than working with the only available Canadian service provider, Chem-Security in Swan Hills, Alberta.

\footnotetext{
122 Pope and Talbot $v$ Canada, interim award, para 104.

${ }^{123}$ By the 1980s SD Myers Inc had branches in South Africa, Mexico and Australia and was looking to expand its business empire further afield.

${ }^{124}$ PCBs (polychlorinated biphenyls) are mixtures of synthetic organic chemicals with the same basic chemical structure and similar physical properties ranging from oily liquids to waxy solids. Due to their non-flammability, chemical stability, high boiling point and electrical insulating properties, PCBs were used in hundreds of industrial and commercial applications including electrical, heat transfer, and hydraulic equipment. More than 1.5 billion pounds of PCBs were manufactured in the United States prior to cessation of production in 1977. Concern over the toxicity and persistence in the environment of PCBs led Congress in 1976 to enact $\S 6(\mathrm{e})$ of the Toxic Substances Control Act (TSCA) that included among other things, prohibitions on the manufacture, processing, and distribution in commerce of PCBs. [Source: The US Environmental Protection Agency (EPA) at http://www.epa.gov/opptintr/pcb/; accessed 25 Oct 2009).

125 Toxic Substances Control Act 15 U.S.C. S/S 2601 et seq. (1976).
} 
In the US, the environmental regulation authorities began considering SD Myers' request for a relaxation of the trading ban in early 1995. Canadian environmental officials and firms followed the developments with keen interest. In July 1995, before the US environmental authorities had favourably considered the request of SD Myers, the Canadian Minister for the Environment stated that government policy on PCB disposal was that "the handling of PCBs should be done in Canada by Canadians". On 26 October 1995 US environmental authorities issued SD Myers a written notice of "enforcement discretion" under which imports of PCBs from Canada into the US for disposal (by destruction) would be allowed between 15 November 1995 and 31 December 1997. Subsequent to the issue of the notice, Chem-security wrote to the Canadian Minister for the Environment urging a quick Canadian response to the US opening of the border to trade in PCBs. On 16 November 1995, a day after the border was "opened", the Minister signed an interim order that had the effect of closing the border from the Canadian side by amending Canada's PCB waste export regulations to prohibit the export of Canadian PCBs. ${ }^{126}$ The interim order was confirmed by Canada's Privy Council on 28 November 1995 and made into an order-in-council of the Governor-General on 26 February 1996. One year later, in February 1997, Canada reversed the closed border policy, amending the PCB waste export regulations to allow PCB shipments to the US. ${ }^{127}$

In this case, the temporary ban by the Canadian government on the export of PCB waste to the US was found to be primarily protective to the Canadian PCB disposal industry against US competition and environmentally unjustifiable but not "tantamount to expropriation". The Tribunal, however, recognised that compensating for a regulatory taking was an exception rather than a rule. ${ }^{128}$

The Tribunal acknowledged that an expropriation usually amounts to a lasting removal of the ability of an owner to make use of its economic rights. ${ }^{129}$ In this case, however, it noted that the closure of the border resulting from the regulation,

126 The Canadian environment minister claimed that the ban was based on environmental policy, in particular the Basel Convention on the control of transboundary movements of hazardous wastes and their disposal (1999). That convention has two relevant provisions. Art 4 (2) (b) calls on parties to "ensure the availability of adequate disposal facilities to the extent possible" within their own boundaries. Art 4 (2) (d) commits governments to "ensure that the transboundary movement of hazardous and other wastes is reduced to the minimum consistent with the environmentally sound and efficient management of such wastes". Notwithstanding the Basel convention, Canada had consistently allowed PCB exports to the US in terms of the two countries' bilateral agreement on the transboundary movement of hazardous waste.

127 This window of commercial opportunity for SD Myers was closed for a good five months later by a US court decision that the 1995 "enforcement discretion" from the US environmental authorities was contrary to the Toxic Substances Control Act.

128 The Tribunal noted that the general body of precedent usually does not treat regulatory action as amounting to expropriation. Regulatory conduct by public authorities is unlikely to be subject to legitimate complaints under article 1110 of the NAFTA, although the Tribunal did not rule out that possibility: SD Myers v Canada, Final Award on Merits, para 69].

129 The Tribunal noted, however, that in some circumstances even a temporary removal of such rights might qualify as an expropriation. 
during which the complainant said it lost its competitive advantage, was only temporary and thus would not amount to an expropriation.130 The Tribunal concurred with the decision in Pope and Talbot $v$ Canada ${ }^{131}$ that the term "tantamount to expropriation" in article 1110 merely meant equivalent to expropriation and the use of the word "tantamount" was meant only to include the concept of creeping expropriation. ${ }^{132}$ Thus the Tribunal effectively ruled that a regulatory expropriation had to result in a substantive deprivation, thus seeming to shut the door on the allegation that NAFTA provides a cause of action for something less, in substantive terms, than a direct expropriation.

\subsection{Metalclad v United Mexican States}

In this case the subject of the dispute was the refusal of local government authorities to issue a permit for the operation of a hazardous waste facility that had already been constructed. The Mexican federal environmental agency repeatedly and consistently approved of Metalclad's project. The state and local political officials who, with equal persistence, disagreed with and tried to counteract the federal environmental determinations, did so without directly contradicting the federal permitting decisions. The state governor's declaration of an ecological zone to protect some rare species of cactus in a large region bore only a tangential relationship to environmental hazards resulting from hazardous land filling.

The Tribunal in Metalclad found that the making of the municipal decision denying the local construction permit - in a hastily convened meeting without notice to the applicant or giving it due opportunity to appear - was deficient in terms of international law notions of due process implicit in fair and equitable treatment. The Tribunal therefore found that expropriation had taken place. ${ }^{133}$

The Tribunal adopted a relatively expansive interpretation of expropriation. ${ }^{134}$ It held that the treatment of Metalclad by local Mexican authorities was inequitable

\footnotetext{
${ }^{130}$ Such a ruling appears to leave the door wide open to a future finding of an expropriation for a measure that is only temporary.

131 Above, para 5.2.

132 SD Myers v Canada, Final Award on Merits, paras 285 -286. However, the Tribunal then added that the term "tantamount" meant that it should look at the substance of what has occurred and not just the form. In other words, a tribunal "must look at the real interests involved and the purpose and effect of the government measure": ibid, para 285].

133 Metalclad v United Mexican States, para 103.

${ }^{134}$ It stated that expropriation under NAFTA includes not only open, deliberate and acknowledged takings of property, such as outright seizure or formal or obligatory transfer of title in favour of the host state, but also incidental interference with the use of the property which has the effect of depriving the owner, in whole or in significant part, of the use or reasonably-to-be-expected economic benefit of property even if not necessarily to the obvious benefit of the host state: Metalclad v United Mexican States, para 109.
} 
and amounted to an indirect expropriation. ${ }^{135}$ Inter alia, the reasons for this finding were the bias of federal government authorities against Metalclad, its flagrant violation of the principle that the affected party had to be represented, and the fact that the authorities had failed to lay a tangible basis, grounded in law or fact, for the refusal of a permit. This refusal had the effect of permanently barring the use of the land fill.

In contrast to $S D$ Myers, the Tribunal ruled that the government need not have acquired a benefit for an expropriation to occur. Moreover, the Tribunal ruled that the fact that a government did not intend to effect an expropriation was not relevant to the determination of whether an expropriation took place. ${ }^{136}$

At the same time, however, the Tribunal narrowed the substantive scope of an indirect expropriation by viewing as functionally equivalent the concepts of "indirect expropriation" and acts or measures "tantamount to expropriation". This finding should help lay to rest claims that NAFTA chapter 11 somehow expands the customary international law definition of expropriation. ${ }^{137}$

The above cases are important in as far as they show how disputes under NAFTA chapter 11 have been handled thus far. They are also central in that they show that environmental standards and regulations may be used to protect local industries from international competition, thus violating the fundamental principles of national treatment and the most favoured nation treatment. The NAFTA tribunals so far have handled the disputes quite well despite some controversies associated with the interpretation of expropriatory provisions.

However, there remain several issues of grave concern raised by Metalclad.138 Firstly, the Tribunal held that by tolerating the actions of the municipality and the patently biased actions of state and federal officials who failed to sufficiently clarify the situation for Metalclad, Mexico had failed in its duty to provide a transparent, clear and predictable framework for foreign investors. The implication here is that an onerous duty rested on the Mexican government to take the company through the complexities of Mexican municipal, state and federal law. Further, the implication of the decision is that the Mexican government was required to ensure that the officials at the various levels of federal, state and local government never gave contradictory advice. ${ }^{139}$ On a related note, the decision in Metalclad does to some extent undermine local control because the definition of expropriation given by the Tribunal was sufficiently broad to include legitimate rezoning by a

\footnotetext{
135 The immediate observation above shows the tribunal adopting a more expansive approach to expropriation, which could see a future tribunal finding an expropriation even where an incidental interference occurred that deprived the owner of a 'reasonably-to-be-expected' benefit.

${ }^{136}$ Soloway (fn 114 above) at 141.

137 Weiler TJ "Metalclad v Mexico: A play in three parts" (2001) 2 Journal of World Investment 60.

138 See, generally, International Institute for Sustainable Development (IISD) "A Backgrounder on the Controversial Case under NAFTA's Chapter 11, and on IISD's Involvement" at http://www.iisd.org/investment/methanex bacground.asp (accessed 3 June 2010).

139 IISD (fn 138).
} 
municipality or other zoning authority. Permit requirements and environmental land use controls at the local level are the preserve of local government which should not have their judgments second-guessed by NAFTA tribunals.

The case also carries some major implications for the status of domestic law visà-vis the NAFTA Tribunal determinations. The panel felt competent to decide complicated issues of Mexican domestic law such as whether a municipal permit was required. ${ }^{140}$ In addition to ruling that the municipality's actions amounted to expropriation, the panel further found that the municipality acted ultra vires its powers in denying Metalclad the construction permit based on environmental concerns. ${ }^{141}$

While the NAFTA Tribunal purported to resort to Preamble provisions to support its reasoning in the case, it is worth noting that it completely ignored other language in the Preamble supporting sustainable development and environmental protection. ${ }^{142}$ Further disregard for environmental considerations is evidenced by the fact that, despite a finding by the panel that the Ecological Decree constituted further grounds for a finding of expropriation, the panel decided that it need not consider the motivation or intent for the adoption of the Decree. ${ }^{143}$

The panel may be commended for its expansive and broad definition of "takings". The Tribunal defined expropriation as not only "open, deliberate and acknowledged takings" of property such as outright seizure, but also "covert or incidental interference" with the use of property. ${ }^{144}$

From the three cases discussed above, two major lessons emerge. Firstly, they illustrate that governments may be at peril if they adopt measures having the effect of expropriating foreign-owned assets, directly or indirectly. Secondly, the disputes show that the use of trade instruments to achieve public policy goals must be meticulously thought out and supported with impeccable scientific support.

\subsection{Some modest lessons for SADC?}

From the above exposition of case law, a few useful lessons for the SADC region in the context of investment protection emerge. While the Campbell litigation was

\footnotetext{
140 Ibid.

${ }^{141} \mathrm{Ibid}$. By so ruling, the panel pronounced on the substance of Mexican domestic law declaring that the exclusive authority for setting and permitting a hazardous waste landfill resides with the Mexican federal government.

142 IISD (fn 138). The panel also ignored Article 1114 of Chapter 11, which purports to protect NAFTA nations from a race-to-the-bottom in environmental standards.

$143 \mathrm{Ibid}$. The motivation for the adoption of the Decree was obviously environmental, hence the panel should have emphasised such motivation supported by the Preamble and pertinent provisions of Chapter 11 of NAFTA.

144 Ibid. It is submitted that this definition of "takings" clearly is much broader than what is allowed by US Courts and could have a crippling effect on the ability of NAFTA nations to carry out traditional governmental regulatory functions.
} 
about land and discriminatory expropriatory laws that make no provision for compensation, it can also be viewed as a potential investment dispute. The fact that the Zimbabwean government has displayed a stubborn reluctance to abide by the decision points at the weaknesses in the SADC legal implementation regime rather than weaknesses in the substantive legal provisions as such. However, the remedies provided in the Protocol on Finance and Investment Protection seem at face value to be robust since they also provide room for international arbitration. The chances of the Zimbabwean government abiding by the Tribunal decision would have been improved by the moral pressure occasioned by the possibility of being dragged to an international arbitration tribunal.

It is submitted that NAFTA Chapter 11 provisions are likely to be influential in future SADC investment protection disputes. ${ }^{145}$ This submission has, however, to be viewed in the context of NAFTA being a regional agreement. Therefore its jurisprudence can only be persuasive to SADC and its Tribunal. Furthermore, the efficacy of the pertinent NAFTA provisions is also subject to the disclaimer that a wholesale adoption thereof by SADC would be ill-advised because of the controversy associated with the erosion of territorial sovereignty as shown by the application of Chapter 11 in practice. These and other concerns will have to be eventually dealt with when the SADC Protocol provisions dealing with protecting investments against expropriation come into force and are litigated.

Another positive aspect of NAFTA, often touted by writers and commentators as novel and an eye-opener for other regional trade groupings, is a provision for "forum shopping". 146 A right is recognised in NAFTA for the parties to the Agreement to resort, at the choice of the complaining party, to one or other dispute settlement mechanism when the dispute involves issues covered by both the World Trade Organisation (WTO) ${ }^{147}$ and NAFTA. ${ }^{148}$ This development is good for the politically weaker party as it enables it to benefit from the superiority of the multilateral dispute settlement mechanism. ${ }^{149}$

On a related note, the investor-to-state provisions of the NAFTA dispute resolution mechanism diverge from dispute resolution systems in previous economic agreements in two ways. First, previous agreements allowed only national

145 The SADC legal regime on investment protection as spelt out in the Protocol is yet to come into operation. One would assume that the Tribunal would take advantage of NAFTA jurisprudence on the expropriation of investments and customise it to the SADC context.

146 See specifically in this regard Loungnarath V. and Stehly C "The General Dispute Settlement Mechanism in the North American Free Trade Agreement and the World Trade Organisation System: Is North America Regionalism Really Preferable to Multilateralism?" (2000) 34 Journal of World Trade 39 at 40.

147 All current SADC member states are members of the WTO. The SADC principles and rules regulating international trade between members are based on their WTO counterparts. In essence, the SADC Protocol on Trade is an attempt by the regional grouping to adapt WTO rules to the SADC municipal context.

148 See Art 2005 of NAFTA.

${ }^{149}$ Loungnarath and Stehly (fn 146 above) at 46. 
governments to bring suits; 150 second, these agreements did not allow for monetary compensation. ${ }^{151}$ The provision for monetary compensation in the NAFTA text is again novel and should be welcomed as a possible deterrent to the flouting of environmental norms by nation states. SADC may pluck a leaf from such a provision and incorporate it in its emerging investment dispute settlement regime.

It has also been argued that the NAFTA Chapter 11 dispute settlement mechanism is an affront to the principle of sovereign immunity. ${ }^{152}$ This attack on the principle of sovereign immunity has grave implications, such as the unfortunate possibility that foreign corporations from outside the US will be granted rights and privileges which are not allowed to domestic corporations in the US. ${ }^{153}$ Allied to the above criticism is the fact that state and local governments are not safe from the NAFTA tribunals' reach. ${ }^{154}$

\section{CONCLUSION AND RECOMMENDATIONS FOR SADC LAW REFORM}

Despite the fact that the Zimbabwean government has largely ignored the Tribunal ruling in the Campbell dispute and has even gone to the extremes of insinuating that the Tribunal has no legal jurisdiction over the country, the case has made an immense jurisprudential contribution to SADC law. ${ }^{155}$ It is now in theory possible for SADC governments to be hauled before the Tribunal for violating provisions of the SADC Treaty or any of its Protocols. It would have been more than ideal if the SADC Protocol on Investment were fully operational so that it could be used alongside the Treaty to protect investments in the SADC region.

With the foregoing in mind, this paper makes the following recommendations.

Currently, the SADC Tribunal is a paper tiger. It can therefore be confidently pointed out that the Tribunal should be equipped with "teeth" as a matter of

\footnotetext{
150 This is the current situation obtaining in the WTO; the same sentiment applies to SADC in transition.

151 In the WTO a complaining country that gets a ruling in its favour may, depending on circumstances, be authorised by the Dispute Settlement Body (DSB) to suspend concessions that it hitherto extended to the defending country or take retaliatory measures against the defendant state; in the extreme, sanctions may be imposed against the offending WTO member by the complaining state.

152 According to the principle of sovereign immunity, governments cannot be sued unless the lawsuit is expressly allowed by the law.

153 IISD (fn 138 above).

154 Ibid. Federal laws such as the US "Buy America" procurement law and a variety of measures taken by state, provincial and municipal governments have been challenged under NAFTA chapter 11 .

155 It is, however, saddening to report that at the time of writing, the Tribunal could not hear any new matter pending a review of its rules and procedures instigated by politicians irked by the finding in the Campbell case. According to Musarurwa TG "Human Rights, SADC and the SADC Tribunal" (2010) (1) SADC Tribunal Review 6, a review of the role, functions and terms of reference of the Tribunal would be undertaken and concluded within six months.
} 
urgency. The provisions relating to the enforcement of the Tribunal's findings must be reformed to remove the requirement that non-compliance with the Tribunal ruling must first be referred to the SADC summit. At the Summit, political considerations and diplomacy play a more prominent role at the expense of legal considerations and fidelity to the rule of stare decisis. This surely does not auger well for a legal system in its nascent stages of development. The rulings of the Tribunal must become effective immediately so that no country can delay the application of an adverse finding against it through references and counterreferences to the SADC Summit.

Secondly, the Tribunal rules should be rewritten to clearly spell out the specific remedies that are immediately available to a plaintiff should a favourable ruling be given. This would ensure that while governments are adopting delaying tactics by referring disputes to the Summit and back, the injured party may mitigate its loss by resorting to remedies such as compensation which accrue immediately after a ruling is given. This may be subject to the proviso that the plaintiff's entitlement to interim remedies of this nature would not be contingent on a referral to the Summit. Tied closely to this point, SADC should come up with a face-saving mechanism which ensures that Tribunal rulings are not belittled and ignored with impunity, as happened in the Campbell case.

Finally and perhaps on a controversial note, there is also a need to clearly spell out the status of the SADC Tribunal vis-à-vis domestic courts in each of the SADC member states. It will be recalled that in the case of Etheredge, 156 Gowora J remarked that the supreme law of Zimbabwe is spelt out in that country's Constitution and there is no statute that puts the SADC Tribunal in a superior position to the courts of Zimbabwe. Such an unfortunate state of affairs can only be remedied by an express reference to whether or not the SADC Tribunal is inferior to domestic courts in the individual countries. It is submitted that the best way forward would be to leave the SADC Tribunal as the apex body in all disputes that it adjudicates and disposes of. This would ensure that all matters decided at Tribunal level are not further litigated at the domestic court level. Therefore the SADC Tribunal would be the Supreme Court in all matters brought to it. As a consequence the domestic courts in the individual countries should recognise the decisions and not scurrilously question and belittle them, as happened in the Etheredge case.

It is important that the foregoing recommendations be read together with the lessons for the SADC as extracted from NAFTA and highlighted in paragraphs 5 and 6 above. It is therefore appropriate to end this paper on a biblical note by

156 Etheredge $v$ Minister of State for National Security Responsible for Lands, Land Reform and Resettlement and Another (fn 69 above). See, on a related note, Gramara (Private) Limited and Another v Government of Zimbabwe and Others, 26 January 2010 (HH 169-2009, HC 33/09) available at http://www.kubatana.net/docs/landr/high court patel gramara goz 100126.pdf (accessed 8 February 2011) at 22-26. 
emphasising that SADC must take a cue from the three wise men from the East and follow the "NAFTA star"; it will surely lead to investment justice.

\section{BIBLIOGRAPHY}

\section{Books and Articles}

Brand J and Krynauw M "Implications and Ramifications of Zimbabwe/SA Agreement on Investment Protection" at http://www.bowman.co.za/ lawArticles/Law-Article id 132417448.asp (accessed 8 August 2010).

Coldham S "The Land Acquisition Act, 1992 of Zimbabwe" (1993) 37 Journal of African Law 82.

Dodge W.S “Customary International Law and the Question of Legitimacy" (2007) 120 Harvard Law Review Forum 19.

Dolzer R and Schreuer C Principles of International Investment Law London: Oxford University Press (2008).

Dube $\mathrm{M}$ and Midgley R "Land Reform in Zimbabwe: Context, Process, Legal and Constitutional Issues and Implications for the SADC Region" (2008) Monitoring Regional Integration in Southern Africa Yearbook 2008.

International Institute for Sustainable Development (IISD), "A Backgrounder on the Controversial Case under NAFTA's Chapter 11 and on IISD's Involvement" at http://www.iisd.org/investment/methanex bacground.asp (accessed 3 June 2010).

Loungnarath V and Stehly C "The General Dispute Settlement Mechanism in the North American Free Trade Agreement and the World Trade Organisation System: Is North America Regionalism Really Preferable to Multilateralism?" (2000) 34 Journal of World Trade 39.

Magaisa AT "The Land Question and Transitional Justice in Zimbabwe: Law, Force and History's Multiple Victims" (Working paper, Oxford Transitional Justice Research) available at http://www.csls.ox.ac.uk/documents/magaisaLandinZimbabweRevised290610.p df (accessed 15 August 2010). 
McGinnis J0 "The Comparative Disadvantage of Customary International Law" (2006) 30 Harvard Journal of Law and Public Policy 7.

Musarurwa TG "Human Rights, SADC and the SADC Tribunal" (2010) (1) SADC Tribunal Review 6.

New Zimbabwe "Germans Fume over Farm Seizures" at http://www.newzimbabwe.com/news-2669-germans+fume+over+farm (accessed 18 June 2010).

OECD Secretariat (2004) "Indirect Expropriation and the Right to Regulate in International Investment Law", Working Papers on International Investment number 2004/4 2-22.

Palmer R Land and Racial Domination in Rhodesia London: Heinemann Educational (1977).

Report of the Africa All Party Parliamentary Group of the UK Parliament "Land in Zimbabwe: Past Mistakes, Future Prospects" (2009) at 26.

Ruppel OC and Bangamwabo FX "The SADC Tribunal: A legal Analysis of Its Mandate and Role in Regional Integration" (2008) Monitoring Regional Integration Year Book 2008 at 5.

Schlemmer EC "Protection of Investors and Investments" (2009) SA Merc LJ 734 at 746.

Short C, former Secretary for International Development in the British government: Letter to Hon Kumbirai Kangai, Zimbabwe Minister of Lands, Agriculture and Rural Development, available at http://www.swans.com/library/art9 Lankomah5.html (accessed 6 July 2010).

Soloway J "Environmental expropriation under NAFTA Chapter 11: The Phantom menace" in Kirton J.J and Maclaren V.W (eds) Linking Trade, Environment and Social Cohesion: NAFTA experiences, Global challenges Toronto: Ashgate (2002).

The Gospel according to St Paul, Chapter 1 verse 1, New English Bible New York: American Bible Society.

Tshuma L A Matter of Injustice - Law, State and the Agrarian Question in Zimbabwe SAPES Books, Harare (1997).

US Environmental Protection Agency (EPA) at http://www.epa.gov/opptintr/pcb/ (accessed 25 October 2009). 
Vagts DF "International Relations Looks at Customary International Law: A Traditionalist's Defence" (2004) 15 The European Journal of International Law 1031-1040.

Vicuna FR "Foreign Investment Law: How Customary is Custom?" (2005) 99 American Society of International Law 97-101.

Weiler TJ "Metalclad v Mexico: A play in three parts" (2001) 2 Journal of World Investment 60.

Zimbabwe Situation "AfriForum to Take Legal Steps against SA Government over Zim Land Attacks" at www.zimbabwesituation.com/afriforum (accessed 19 June 2010).

Zimbabwe's Ministry of Lands and Agriculture at http://www.moa.gov.zw/ (accessed 15 June 2010).

Zongwe DP “Contribution of Campbell v Zimbabwe to the Foreign Investment Law on Expropriations" (2009) 5 CLPE Research Paper at i.

\section{Cases}

Metalclad $v \quad$ United Mexican States, 2000 (available at http://ita.law.uvic.ca/documents/MetacladAward-English.pdf, accessed 8 February 2011).

Bernardus Henricus Funnekotter and Others $v$ Republic of Zimbabwe (ICSID case no. $\mathrm{ARB} / 05 / 6)$.

Commercial Farmers Union v Minister of Lands 2001 (2) SA 925 (ZSC) at para 9.

Davies and Others v Minister of Lands, Agriculture and Water Development 1994 (2) ZLR 294 (H).

Etheredge $v$ Minister of State for National Security Responsible for Lands, Land Reform and Resettlement and Another [HC 3295/08) [2009] ZWHHC 1 (4 February 2009).

Gramara (Private) Limited and Another $v$ Government of Zimbabwe and Others, unreported case, no: HC 5483/09; available at http://www.kubatana.net/ docs/landr/high court patel gramara goz 100126.pdf (accessed 8 February 2011).

In re Rhodesia (1919) AC 210. 
Mike Campbell (Pvt) Ltd v Minister of National Security Responsible for Land, Land Reform and Resettlement (SC 49/07).

Mike Campbell and Others v Republic of Zimbabwe SADC (T) Case No. 2/2007.

Pope and Talbot $v$ Canada (2002) 41 ILM 1347 at http://www.state.gov/ documents/organisation/407.pdf (accessed 5 August 2009).

SD Myers Inc v Canada, Partial award 13 November 2000, Ethyl Corporation v Canada (complete records available at http://www.international.gc.ca/trade-agreementsaccords-commerciaux/disp-diff/SDM archives.aspx?lang=en, accessed 8 February 2011).

\section{Acts}

Constitution of Zimbabwe Amendment (No. 11) Act 30 of 1990.

Land Apportionment Act of 1930.

Land Tenure Act of 1969.

Zimbabwe Constitutional Amendment No. 16 of 2000.

Zimbabwe Constitutional Amendment No. 17 of 2005.

Toxic Substances Control Act 15 U.S.C. S/S 2601 et seq. (1976).

\section{Agreements}

Agreement on Encouragement and Reciprocal Protection of Investments between the Republic of Zimbabwe and the Kingdom of the Netherlands, Dec 11, 1996.

Basel Convention on the control of Transboundary Movements of Hazardous Wastes and their Disposal (1999).

Bilateral Investment Promotion and Protection Agreement (BIPPA) between Zimbabwe and Germany (1995).

Protocol on Rules of Procedure of the SADC Tribunal, available at http://www.sadctribunal.org/pages/protocols.htm (accessed 5 August 2010). 